\title{
Evaluation of Peatland Suitability for Rice Cultivation using Matching Method
}

\author{
Juhriyansyah Dalle ${ }^{1 *}$, Dwi Hastuti², Firdaus Akmal ${ }^{1}$ \\ ${ }^{1}$ Department of Information Technology Universitas Lambung Mangkurat, Banjarmasin, South Kalimantan, Indonesia \\ ${ }^{2}$ Department of Industrial Engineering Universitas PGRI Adi Buana Surabaya East Java, Indonesia
}

Received: 22 April 2020

Accepted: 9 September 2020

\begin{abstract}
One of the common problems with peatlands is the infertile nature of the soil, therefore, farmers need to possess adequate knowledge on land evaluation techniques within a limited period to grow crops in this region optimally. Therefore, this research aims to design and build a computerized system to evaluate the suitability of land for rice cultivation by using the matching method based on FAO guidelines. This study develops a web application that enables users to store the various characteristics of the land and easily output suitable information with limiting factors. A total of 14 data inputs with 22 land characteristics parameters were used in the system trial phase. The result showed that the system testing results when compared with the manual calculations, obtained a $92.86 \%$ level of accuracy. Therefore, further research is needed on the use of the application on land suitability evaluation for growing other types of crops apart from lowland rice. In addition, the input parameters can be adjusted based on future land suitability evaluations, with the system developed to evaluate the criteria and pave the way for future research development in the field.
\end{abstract}

Keywords: land evaluation, land evaluation web system, web-based matching

\section{Introduction}

Along with the surging world population, there comes a continuous increase in demand for new technologies with shortages of land or waterlogged and facing specific soil and climate challenges [1]. In Indonesia, agricultural demand for arable land, specifically for rice cultivation has led to the search for suitable soils, which can be obtained through efficient measures, such as the use of technology in evaluating land suitability.

*e-mail: j.dalle@ulm.ac.id
Furthermore, the limited amount and lack of suitable unutilized uplands, as well as the increasingly attractive nature of available peatlands and their flat topography [2], have led to the use of peat soils as alternative areas for rice cultivation. Subsequently, in an effort to establish appropriate and suitable peatlands for rice cultivation in Indonesia, a matching method has been developed as a guide.

Land evaluation for suitability is a prerequisite due to the unique quality and functions of peatlands [3]. According to studies, peatlands are a delicate piece of land whose suitability is a requirement for achieving optimum use [4]. Therefore, the advance use of information system is needed to determine the right method suitable for food production and cultivation on 
peatlands. Furthermore, proper handling of peatlands is associated with the efficient management of natural resources which is fundamental for ensuring food security and sustainability of the environment in the agricultural sector [5].

According to [6], the existing challenges and limitations regarding the availability of arable soils make the utilization of peatlands for food cultivation a necessity. Therefore, reliable and affordable techniques are needed to facilitate good agricultural practices, using the already existing innovative methods and technologies that can be applied in the identification of suitable cropland [7].

The evaluation of peatland to determine its suitability in rice cultivation is necessary for Indonesia because the country has over 14.91 million ha of peatlands spread across the archipelago. This comprises of over 6.44 million ha (43\%), 4.78 million ha $(32 \%)$ and 3.69 million ha $(25 \%)$ of the total land cover in Sumatra, Kalimantan and Papua islands, respectively [8]. However, irrespective of the large landmass of peatlands, its use of agricultural purposes, such as rice cultivation, remains limited. In 1995, a Mega Rice Project was launched in tropical peatland of Central Kalimantan. However, this project failed due to the limited knowledge regarding peatland hydrology, high water levels, the subsidence of peats, poor drainage systems, inadequate farming technology [8], etc. Therefore, this study aims to design and build a computerized system that can evaluate the suitability of land for rice cultivation, using the matching method based on FAO guidelines. According to [9] the fertility of peatlands is mostly determined by three property components, namely thickness, source of inundating water, and type of mineral soil below the peat. These three-property components are easily identified through the use of modern technological systems. Furthermore, the suitability of peatland for food cultivation is important due to its ability to increase peat depth, as well as the distance from the main river. It also leads to low fertility because water is a basic component in many processes on earth and its permanent presence in the landscape leads to the emergence of many unique and valuable habitats such as peatlands [10] and contributes to numerous soil nutrients.

The assessment of land suitability for agriculture is a complex, multidisciplinary and multi-criteria process, which considers the source of topography, climate, availability of water resources for irrigation, soil capability and current management practices including land use and cover [11]. Furthermore, adequate knowledge of the right strategies to improve the deficiencies of land is also needed to prevent less optimal productivity of crops. Subsequently, land evaluation knowledge accessible by farmers and related parties needs to be obtained and availed in a short period [12]. Various criteria can be used to evaluate land suitability for agricultural use such as by considering several factors including agricultural methods, data availability, evaluation accuracy, environmental characteristics of the study area, and crop types [13]. Therefore, the use of a non-computerized process of land evaluation is likely to take a long time assuming a lot of data need to be processed. This research also focuses on understanding environmental problems felt by farmers and contributing their knowledge to relevant authorities in the area for better planning and decisionmaking towards the use and conservation of resources [14].

Land suitability in this study is determined using the matching method, which is based on the Food and Agriculture Organization (FAO) guidelines being the organization's internationally mandated to handle issues associated with food [15]. The matching method is often used to evaluate land suitability due to its simple flow and limiting factors. This technique can also be directly programmed into a computer application that does not require much training. Therefore, based on the above insights, this study developed a web-based system capable of handling the problem of determining land suitability automatically. It is expected that with this system, various parties related in the agriculture sector, particularly in peatland rice cultivation can be quickly facilitated and easily used to evaluate land suitability.

\section{Conceptual Review}

Several studies have been conducted on systemic land suitability evaluation. For instance, the research conducted by Habibullah and Winiarti [12] analyzed a web-based decision support system using the similarity method with 10 land characteristics. In addition, a matching method that compares land characteristics as parameters measured in the field and laboratory was used to evaluate land suitability with classes compiled based on plant growth requirements to determine minimum limiting factors [16].

According to [17], the quality of land used in agriculture affects the productivity of the crops cultivated. Rice production in Indonesia has continuously increased every year. For instance, from 2015 to 2016 there was a $5.25 \%$ increase from by 75 million tons to 79 million tons, with a decrease in productive land from 53.41 hectares to 52.36 hectares due to the unbalanced cultivation strategies utilized [18]. Therefore, it is necessary to determine the potential and obstacles in lands, to obtain an exponential increase in rice productivity.

Peat is an organic-rich soil consisting of the remnants of plant material that is inadequately decomposed [19]. Therefore, in an attempt to determine suitable arable land, farmers tend to spend a lot of money, time, and labor clearing the inappropriate areas and the environment [12]. The size of the agricultural sector in many parts of the world shows that it is the wheel of social and economic growth. However, the sector is currently grappling with increased food 
demand and declining land resources [20]. Therefore, for this reason, it is necessary to determine the potential and inhibiting factors that exist in peatlands, in order to properly utilize it for agricultural purposes, especially for rice cultivation, while avoiding losses.

Taechatanasat and Armstrong [21] proposed an agricultural decision-making framework that focuses on information flow processes. The flow process is designed to help farmers make decisions through information dissemination. Therefore, a system capable of evaluating land suitability is needed to make it easier for those in need of crucial information on land productivity, such as farmers, to determine the right suitable crops to be grown in peatlands [22]. This is because the process of assessing and processing large amounts of data is always carried out quickly using a computerized process [17].

The land is a basic factor for growing crops, therefore, the term land suitability is defined as the ability of certain types of land to support certain uses, which involves evaluating and grouping certain land areas [23]. Furthermore, the potential of land for crop cultivation is referred to as land suitability evaluation for agriculture, which analyzes data relating to soil, topography, vegetation, climate, water conditions and population [24].

\section{Methodology}

This study was carried out using land geology variables and its characteristics as the basis for data collection and analysis. The tools applied in data collection comprised a computer PC running on Windows 7 operating system. The software used to design and develop the website was framework Laravel, while XAMPP, MySQL and Google Chrome were used as web servers, database application management, and a web browser to run the applications, respectively. Furthermore, this approach involved the use of a PC for proper analysis of data due.

The approach aimed to ease the analysis based on geology variables and the land cover features [25]. Data analysis was conducted using the PC to obtain the refined components of the final analysis. In addition, the study used secondary data acquired from the different documents on land suitability evaluation. Table 1 shows the analysis used to identify land characteristics, which is an illustration of the data used in the identification stage.

Farmers and other land users need to understand the characteristics of developing land suitability evaluation and identification for the appropriate use of the land. This is because the land is neither graded as good or

Table 1. Land characteristics.

\begin{tabular}{|c|c|c|c|c|c|c|}
\hline Land Characteristics & 1 & 2 & 3 & 4 & 5 & 6 \\
\hline Average Temperature & 32,8 & 32,8 & 33 & 31,6 & 31 & 34,1 \\
\hline Rainfall & $1200-1500$ & $1200-1500$ & $1200-1500$ & $1200-1500$ & $1200-1500$ & $1200-1500$ \\
\hline Humidity & 55,7 & 56,5 & 55,5 & 55,7 & 57,8 & 53,5 \\
\hline Drainage & hinderances & hinderances & hinderances & hinderances & hinderances & hinderances \\
\hline Texture & $\begin{array}{l}\text { SCL, SiL, } \\
\text { CL }\end{array}$ & $\mathrm{SiL}, \mathrm{CL}$ & $\mathrm{SiL}, \mathrm{CL}$ & $\mathrm{SiL}, \mathrm{CL}$ & $\mathrm{SiL}, \mathrm{CL}$ & $\mathrm{SiL}, \mathrm{CL}$ \\
\hline Depth effectiveness & $>40$ & $>40$ & $>40$ & $>40$ & $>40$ & $>40$ \\
\hline Peat-soil readiness & sapric & sapric & sapric & sapric & sapric & sapric \\
\hline Ketebalan gambut & $<100$ & $<100$ & $<100$ & $<100$ & $<100$ & $<100$ \\
\hline Land formation & 8,62 & 6,55 & 8,31 & 22,43 & 20,26 & 9,21 \\
\hline Saturation & 0,47 & 0,43 & 2,13 & 0,65 & 0,65 & 0,61 \\
\hline Soil pH & 7 & 6 & 5 & 5 & 6 & 6 \\
\hline C-organic & 7,07 & 7,88 & 4,35 & 3,54 & 6,5 & 5,59 \\
\hline Salinity & 0,6 & 0,8 & 0,8 & 0,7 & 0,6 & 0,4 \\
\hline Sulfidic depth & $>75$ & $>75$ & $>75$ & $>75$ & $>75$ & $>75$ \\
\hline Total N & low & average & 1o & average & average & low \\
\hline Surface rocks & $<3$ & $<3$ & $<3$ & $<3$ & $<3$ & $<3$ \\
\hline Outcrop rocks & $<2$ & $<2$ & $<2$ & $<2$ & $<2$ & $<2$ \\
\hline Erosion dangers & SR & SR & SR & SR & SR & SR \\
\hline Slope & $0-3 \%$ & $0-3 \%$ & $0-3 \%$ & $0-3 \%$ & $0-3 \%$ & $0-3 \%$ \\
\hline Dangers of floods & F0-F1 & F0-F1 & F0-F1 & F0-F1 & F0-F1 & F0-F1 \\
\hline
\end{tabular}


bad, best or worst, however there are different uses for each kind or form. According to [26] management practices are also used to determine high water levels needed for rice cultivation. In addition, it is used to determine the efficient transportation needed for tea, sugar cane and palm oil, while stones and rock outcrops are limited to conventional tools for cultivation. Therefore, due to these various requirements, the development of land suitability evaluation databases for agricultural suitability identification is highly needed in modern farming. Table 1 shows the various land characteristics.

Table 1 describes some of the varying characteristics considered during the land suitability evaluation process regarding rice cultivation. Data were collected from available theories, literature, and material on rice cultivation in peatlands.

The data was analyzed using a suitable computer application and processed using the matching method. Furthermore, the analyzed data was implemented using the trial method to test the system's results.

\section{Laravel}

Laravel is a free, open-source PHP web framework, created by Taylor Otwell and intended for web application development following a model-viewcontroller (MVC) architecture pattern [27]. It enhances a user's experience in building the web with clear syntax and functions that saves time [28].

Laravel is one of the new PHP frameworks, with a popular $3^{\text {rd }}$ version with numerous users within a short time. The Laravel repository on GitHub has many high ratings compared to previous frameworks such as Symfony, CakePHP, CodeIgniter and Yii [29].

\section{Matching}

The Profile Matching Method is a technique used as a mechanism in decision making by assuming that there is an ideal level of predictor variables that need to be met by the subjects studied, rather than the minimum level [30].

In the matching process, several aspects need to be considered [31] as follows:

- Land quality in each land mapping.

- Land quality for each land use.

- Land quality rating.

The following equation is used to determine the matching method for land suitability [32]:

$$
S_{\text {land }}=\min \left(S_{\text {par-1 }}, \ldots, S_{\text {par-n }}\right)
$$

Explanation:

$S_{\text {land }}$ : Land suitability

$S_{\text {par }-1}$ : Conformance value in parameter 1

$S_{p a r-n}^{p a r-1}$ : Conformance value on parameter $\mathrm{n}$

From this equation, it can be explained that the results of land suitability are obtained from the

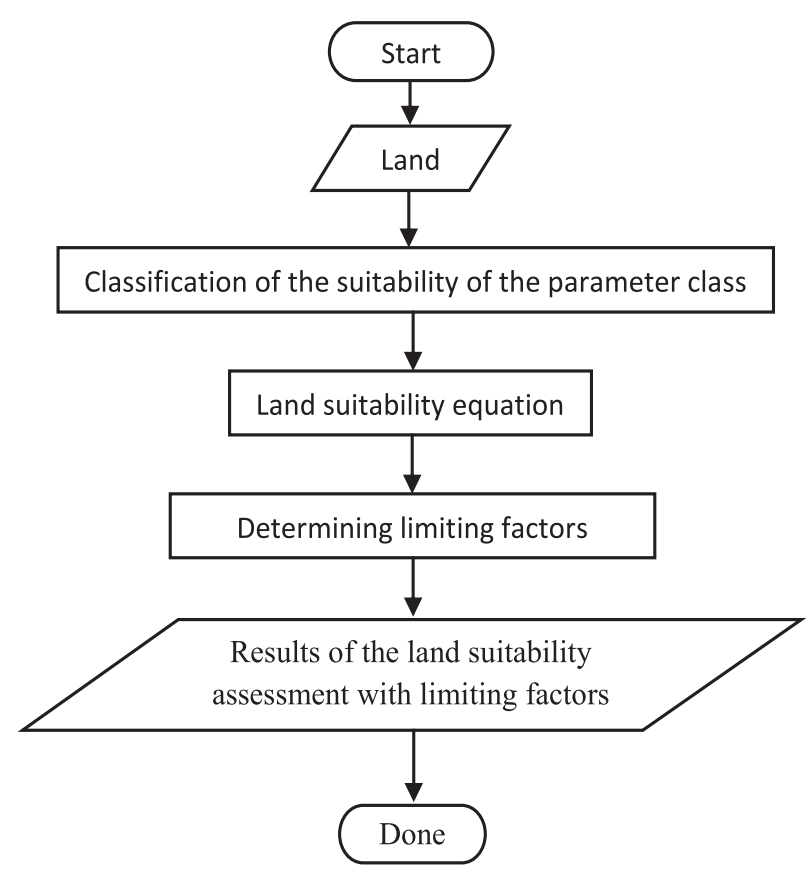

Fig. 1. Data Processing Flow Chart.

minimum value on all parameters. For instance, at the suitability value of S1, S1, S2, S3, N, the land is not suitable for rice cultivation.

\section{Results and Discussion}

The Flow of Data Processing in the System

Input data on the web application is processed with the PHP programming language using the matching method. The data processing in Fig. 1 starts when the land characteristics are entered into the application, followed by data classification according to the suitability parameter class. Furthermore, the data is entered into the minimum equation to obtain the land suitability class, and finally, it is used to determine the limiting factor. Input data processing in a web application is shown in Fig. 1.

\section{System Implementation}

Fig. 2 shows the user interface display of the application input form.

Fig. 2, shows that there are 22 input fields for land characteristics. After filling all the required fields, the user presses the "Process" button to determine the suitability results of the processed land on the results page.

\section{System Testing Results}

In testing the results of the system comparisons were made from the results of the land suitability evaluation report processed by the system using data from other 


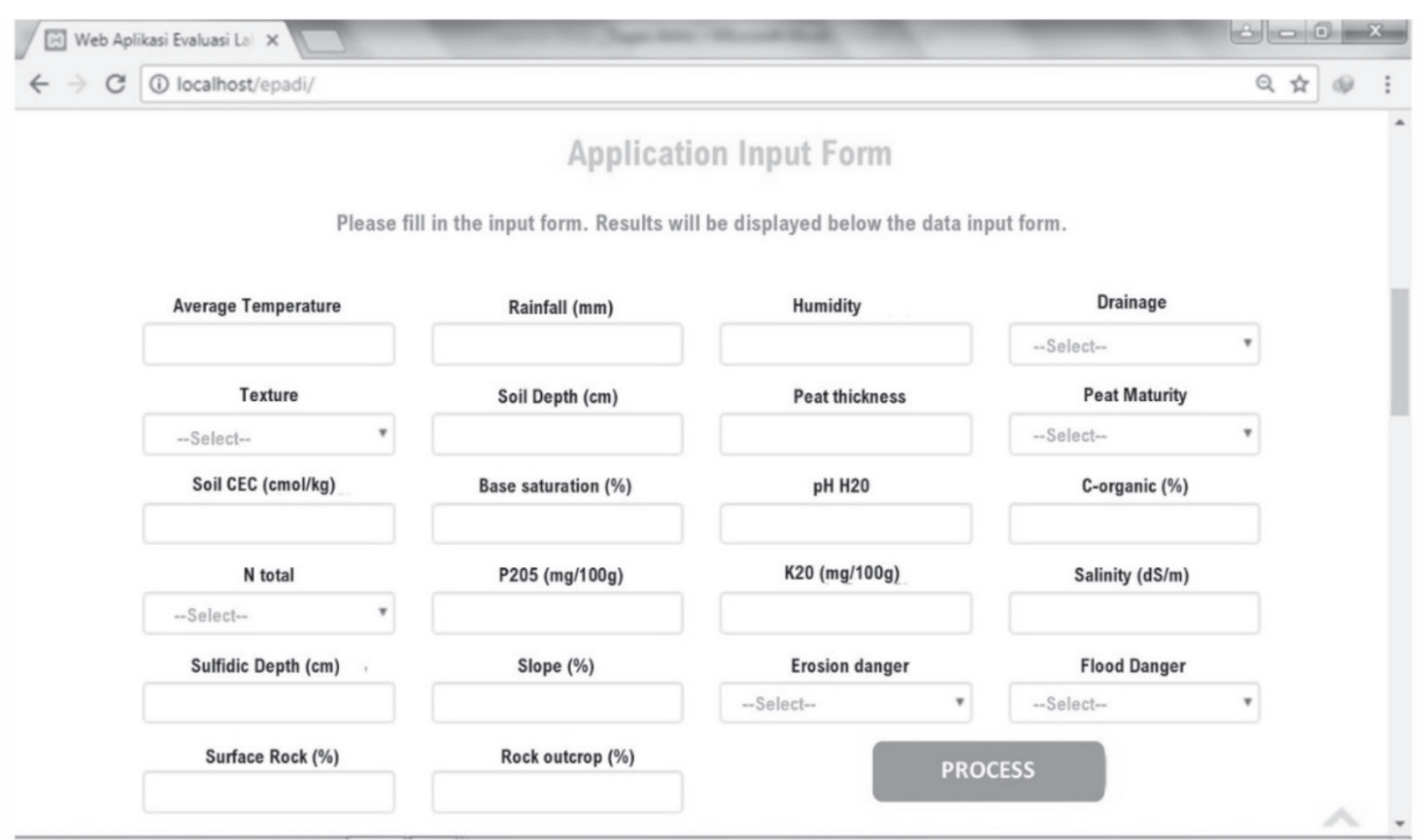

Fig. 2. Application Input Form Interface.

Table 2. Manually calculated system results.

\begin{tabular}{|c|l|l|}
\hline Land Data & \multicolumn{1}{|c|}{ System Results } & \multicolumn{1}{|c|}{ Manual Results } \\
\hline 1 & S3 (Temperature, Base Saturation) & S3 (Temperature, Base Saturation) \\
\hline 2 & S3 (Base Saturation, P205) & S3 (Temperature, Base Saturation) \\
\hline 3 & S3 (Temperature, Base Saturation, P205) & S3 (Temperature, Base Saturation) \\
\hline 4 & S3 (Base Saturation, P205) & S3 (Base Saturation, P205) \\
\hline 5 & S3 (Base Saturation) & S3 (Base Saturation) \\
\hline 6 & S3 (Temperature, Base Saturation) & S3 (Temperature, Base Saturation) \\
\hline 7 & S3 (Temperature, Base Saturation) & S3 (Temperature, Base Saturation) \\
\hline 8 & S3 (Base Saturation) & S3 (Base Saturation) \\
\hline 9 & S3 (Temperature, Base Saturation) & S3 (Temperature, Base Saturation) \\
\hline 10 & S3 (Base Saturation) & S3 (Base Saturation) \\
\hline 11 & S3 (Temperature, Base Saturation) & S3 (Temperature, Base Saturation) \\
\hline 12 & S3 (Base Saturation, P205) & S3 (Base Saturation) \\
\hline 13 & S3 (Base Saturation) & S3 (Base Saturation) \\
\hline 14 & S3 (Base Saturation) & S3 (Base Saturation) \\
\hline
\end{tabular}

studies conducted manually. The results of the manual calculation are shown in Table 2.

Table 2 provides data regarding the computerized and manual results, which are compared to determine land suitability. The result showed that the only difference is in the limiting factors, in both methods, therefore, the level of accuracy of the system can be calculated as follows:

$$
\begin{aligned}
& \frac{\text { data amount }}{\text { data tested }} \times 100 \% \\
& \frac{13}{14} \times 100 \%=92.86 \%
\end{aligned}
$$

From the above calculation, the accuracy of the system results is $92.86 \%$.

\section{Conclusion}

In conclusion, we have reported the results of the development of peatland suitability evaluation systems for web-based rice plants using the matching method provided high accuracy results in determining the suitability of peatlands for rice plants. From our data testing, the accuracy of the system results is more than ninety percent. In addition, this system provides easy 
solutions for farmers to determine the suitability of land before growing crops.

\section{Acknowledgements}

The authors are grateful to the Department of Information Technology, Universitas Lambung Mangkurat for their support provided in writing and publishing this research.

\section{Conflict of Interest}

The authors declare no conflict of interest.

\section{References}

1. BRUINSMA J. World Agriculture: towards 2015/2030: Summary Report (No. BRU 631), Rome (Italy): Food and Agriculture Organization of the United Nations (FAO), 2002.

2. HERGOUALC'H K., CARMENTA R., ATMADJA S., MARTIUS C., MURDIYARSO D., PURNOMO $\mathrm{H}$. Managing peatlands in Indonesia Challenges and opportunities for local and global communities, Center for International Forestry Research (CIFOR), 205, 8, 2018.

3. BONN A., REED M.S., EVANS C.D., JOOSTEN H., BAIN C., FARMER J., EMMER I., COUWENBERG J., MOXEY A., ARTZ R., TANNEBERGER F., UNGER M.V., SMYTH M., BIRNIE D. Investing in nature: Developing ecosystem service markets for peatland restoration, Ecosystem Services, 9, 54, 2014.

4. KIHORO J., BOSCO N.J., MURAGE H. Suitability analysis for rice growing sites using a multi-criteria evaluation and GIS approach in great Mwea region, Kenya, SpringerPlus, 2, 265, 2013

5. DENGIZ O. Land suitability assessment for rice cultivation based on GIS modelling, Turkish Journal of Agriculture and Forestry Turk J Agric For, 3 (37), 326, 2013.

6. SURAHMAN A., SONI P., SHIVAKOTI G.P. Are peatland farming systems sustainable? Case study on assessing existing farming systems in the peatland of Central Kalimantan, Indonesia, Journal of Integrative Environmental Sciences, 1 (15), 1, 2017.

7. BURINGH P. The land resource for agriculture," Series B, Biological Sciences, 310 (1144), 151, 1985.

8. OSAKI M., SETIADI B., TAKAHASHI H., EVRI M. Peatland in Kalimantan, Tropical Peatland Ecosystems, 91, 2016.

9. WAHYUNTO, SUPRIATNA W., AGUS F. Land use Change and Recommendation for Sustainable Development of Peatland for Agriculture: Case Study at Kubu Raya and Pontianak Districts, West Kalimantan, Indonesian Journal of Agricultural Science, 11 (1), 32, 2010.

10. HARENDA K.M., LAMENTOWICZ M., SAMSON M., CHOJNICKI H.B. The Role of Peatlands and Their Carbon Storage Function in the Context of Climate Change, Interdisciplinary Approaches for Sustainable Development Goals, 169, 2018.

11. ALDABABSEH A., TEMIMI M., MAGHELAL P., BRANCH O., WULFMEYER V. Multi-Criteria
Evaluation of Irrigated Agriculture Suitability to Achieve Food Security in an Arid Environment, Sustainability, 10 (803), 1, 2018.

12. HABIBULLAH DAN A., WINIARTI S. Sistem Pendukung Keputusan Penentuan Kesesuain Jenis Lahan Pertanian Untuk Budidaya Tanaman Buah-Buahan Menggunakan Metode Similarity Berbasis Web, Jurnal Sarjana Teknik Informatika, 2 (2), 336, 2014.

13. KARIMI F., SULTANA S., BABAKAN A.S., ROYALL D. Land Suitability Evaluation for Organic Agriculture of Wheat Using GIS and Multicriteria Analysis, Papers in Applied Geography, 4 (3), 326, 2018.

14. CHOUDRI B.S., BAAWAIN M., AL-SIDAIRI A., ALNADABI H., AL-ZEIDI K. Perception, knowledge and attitude towards environmental issues and management among residents of Al-Suwaiq Wilayat, Sultanate of Oman, International Journal of Sustainable Development \& World Ecology, 23 (5), 433, 2016.

15. PARIAMANDA S., SUKMONO A., HANI'AH, Analisis Kesesuaian Lahan Untuk Perkebunan Kopi Di Kabupaten Semarang, Jurnal Geodesi Undip, 5 (1), 116, 2016.

16. NGANJI M.U., SIMANJUNTAK B.H., SUPRIHATI Evaluation of Land Suitability of Main Food Commodities in West Umbu Ratu Nggay District Central Sumba Region, Agritech, 2 (38), 172, 2018.

17. AGUS F., ANDA M., JAMIL A., MASGANTI Lahan gambut Indonesia: pembentukan, karakteristik, dan potensi mendukung, Jakarta: Badan Penelitian dan Pengembangan Pertanian, 2014.

18. KPRI, Lahan Gambut Indonesia: Pembentukan, Karakteristik, dan Potensi Mendukung Ketahanan Pangan, Edisi Revisi, Jakarta: IAARD Press, 2017.

19. LI C., GRAYSON R., HOLDEN J., LI P. Erosion in peatlands: Recent research progress and future directions, Earth-Science Reviews, 185, 870, 2018.

20. DADHICH G., PATEL P.R., KALUBARME M.H., PANDYA M. "Development of Decision Support System for Land Suitability Evaluations for Crops Using ICT Tools," Engineering and Technology in India, 8 (1\&2), 65, 2017.

21. TAECHATANASAT P., ARMSTRONG L. Decision Support System Data for Farmer Decision Making, Edith Cowan University Research Online, 1, 2014.

22. SAILAJA B., VOLUMEETI S.R., SUBRAHMANYAM D., RAO P.R., GAYATRI S., KUMAR R.N., MEERA S.N. Spatial rice decision support system for effective rice crop management, Current Science, 3 (116), 412, 2019.

23. BERA S., AHMAD M., SUMAN S. Land Suitability Analysis for Agricultural Crop using Remote Sensing and GIS - A Case Study of Purulia District, IJSRD - International Journal for Scientific Research \& Development, 5, 1, 2017.

24. MADRIGAL-MARTÍNEZ S., PUGA-CALDERÓN J.R. and Suitability and Sensitivity Analysis for Planning Apple Growing in Mala's Valley, Peru, Bioagro, 30 (2), 1, 2018.

25. LIPSCOMB W.S. Hydrologic Classification and Estimation of Basin and Hydrologic Characteristics of Subbasins in Central Idaho: Issue 1604, US Geological Survey, 1998.

26. FAO, Guidelines for land-use planning. Soil Resources, Management and Conservation Service under the guidance of the Inter-Departmental Working Group on Land Use Planning, Rome: Food and Agriculture Organization of the United Nations, 1993, 1996, pp. 93-96.

27. XIANJUN CHEN Z.J.Y.F.A.Y.Z. Restful API Architecture Based on Laravel Framework, Journal of Physics: Conf. Series, 1, 2017. 
28. MCCOOL S. Laravel Starter, Birmingham: Packt Publishing, 2012.

29. BEAN M. Laravel 5 Essential, Birmingham: Packt Publishing, 2015.

30. HERLAMBANG B.A., DEWANTO F.M., HARJANTA A.T., SETYAWATI V.V. Implementation of Profile Matching Methods In A Mobile Based Adolescent Nutritional Assesment Systems, TRANSFORMATIKA, 16 (1), 1, 2018
31. TRISTANTI D.A.E. Evaluasi Kesesuaian Lahan Untuk Tanaman Padi Kecamatan Tabukan Kabupaten Barito Kuala, 3, 2016.

32. HIDAYAT H.T. Penggunaan Metode Matching Untuk Penentuan Kesesuaian Lokasi Budidaya Rumput Laut Di Kabupaten Sumenep Menggunakan Sistem Informasi Geografi, VIII (03), 35, 2013. 